\title{
A FELELŐS SZERVEZETI EMBER
}

\begin{abstract}
„Manapság vezető emberek szeretik vállalni a felelösséget. Olvasom az újságban, onnét tudom. Vállaljuk a felelösséget, mondják. Ez egy mondat, mondott mondat. Csak hát a felelösség vállalása az nem (csak) egy mondat."
\end{abstract}

\author{
Esterházy Péter
}

Olyan kort élünk, amikor a felelősség fogalma áthatja a közéletet és szervezeteink világát; keressük, azonosítjuk, vágyjuk, hiányoljuk, számon kérjük, tulajdonítjuk, vállaljuk, vitatjuk, tagadjuk egyéni és közösségi szinteken egyaránt. A szerzők többrészes írása egymásra épülő stációkban arra keresi a választ, hogy mit jelent a „felelős szervezeti ember”, s miképpen értelmezik a szervezeti szereplők saját felelősségüket különböző helyzetekben. Egy közszolgálati szervezetben, egy kisvállalkozásban, illetve diákok között kutatják nyomát, jelentését. A sorozat első (jelen) darabja az értelmezési kérdéseket helyezi előtérbe, alapokat, kereteket és fogalmakat adva a vizsgálatok számára.

Kulcsszavak: felelősség, felelősségvállalás, szervezetelmélet, corporate social responsibility (CSR)

A „felelősség” súlyos fogalom; egzisztenciálisan meghordoz bennünket. Társas lényként, kapcsolatban élő személyekként viszonyulásaink alapvető jellemzője, tanulási folyamataink és szervezeti életünk elemi összetevője. Az egyetemi képzésben tanárként és hallgatóként ugyanakkor azt tapasztaljuk, hogy a képzési helyzetekben ehhez képest ritkán fordul elő, illetve előkerülésekor könnyen zavarba hozza a beszélgetésben résztvevőket, akik sokféle tartalmat kapcsolnak hozzá.

Tanulmányainkkal célkitüzésünk, hogy hozzászóljunk a felelősségről szóló diskurzushoz. Tisztázzuk, miként értelmezhető személyes, illetve szervezeti szinten, s felvetésekkel szolgáljunk ahhoz, hogy mit jelent a „felelős szervezeti ember"; a vizsgálathoz a felelősség dimenzióiról saját modellt építsünk, melyet aztán különböző szervezeti keretekben, üzleti és nem üzleti szervezetekben vizsgálunk.

A jelen tanulmányban megjelenő alapozó gondolkodás és modell több megértő célú vizsgálat alapjául szolgál majd, melyek követő publikációinkban lesznek olvashatók.

\section{A felelősség értelmezésének nyomában - a személyes felelősség}

A Magyar Értelmező Kéziszótár (Juhász et al., 1992, p. 374.) szerint a felelösség ,az a kötelezettség, amelynek alapján valaki, valami felelős valakiért, valamiért". A meghatározás magába fordul vissza: a felelősséget a felelősből származtatja. E tekintetben az Etimológiai Szótár egy lépéssel közelebb juttat a formális definiáláshoz, amennyiben a felel szócikkhez releváns értelmezésnek azt adja meg második jelentésként, hogy ,peres ügyben törvény elött válaszol”, valamint ,vállalja, hogy valamiről törvény előtt számot ad" (Zaicz, 2006, p. 199.).

Az idegen nyelvű etimológiai szótárakban történő kutatás hasonló eredményre vezet. A felelősség angolul (responsibility), spanyolul (responsabilidad) és németül (Verantwortlichkeit) is a „felel” igéből származik. Angol megfelelöjét az ófrancia responsible szóból 'válaszadásra kötelezett' jelentéssel vették át a tizenhatodik század végén. A keresztény hagyomány szerint a felelősség az ember válasza Isten megszólítására. Isten a felebaráti szeretetben az embert rábízta a másik emberre, felebarátjára, akiért felelősséggel tartozik.

A következő időszakban a „felelősség” tartalma fokozatosan a számonkérhetőséggel, kötelezettséggel és megbízhatósággal bővült ki (Etymonline, 2001). A Thesaurus szótár szerint a „,felelősség” jelenlegi szinonimái a következők: hatalom, erő, tekintély, számonkérhetőség, kötelezettség, befolyás, kontroll, bizalom, fontosság (2013). Érzékelhető tágasság nyílik hát a meghatározásban: e fogalmak mélyítik, beágyazzák, még inkább a kapcsolati minőség terepére húzzák a kifejezést. A „,kötelezettség” már a Magyar Értelmező Kéziszótár definíciójában is megjelent: a felelőst valamilyen erő kötelezi - odaköti a felelősség tárgyához. A befolyás és a kontroll szavak viszont egyértelmüen utalnak rá: olyasmiért nem lehet valaki felelős, aminek kimenetelére nincs befolyással. A felelősség és a bizalom lényegi összefonódottsága pedig egy újabb rétegébe vezet a fogalmi elemzésnek. „A bizalom alapjában véve pozitív, de komplex és bonyolult, sokféleképpen átélt kapcsolat önmagunkhoz, másokhoz és a világhoz” - írja Schütz (1993). „Tudatossá főként akkor válik a másokkal való kapcsolatban, ha kockázatok, problémák és krízisek merülnek föl, és értelmesen fölébük lehet kerekedni.” Ha „megbízunk valakiben”, az azt a hitünket fejezi ki, hogy valakinek a becsületességére és segítőkészségére minden helyzetben számíthatunk. A bizalom fogalmának egy szükebb értelmezése szerint a bizalom fogalma elsősorban arra utal, hogy bízunk valakinek a szavahihetőségében (lásd Hankiss, 2002). Mindenesetre a bizalom tudatos élményét érzelmek határozzák meg, ezért egyénenként változik, és helyzetektől, emberismerettől, 
viselkedésformáktól függ. A felelősség bizalmon alapuló vállalása és elfogadása egy belső, ha úgy tetszik, lelki ,átadási-átvételi mozzanat".

Amennyiben a felelősséget zártan, csak adott döntésért, cselekvésért való elszámoltathatóságként értelmezzük, akkor az a múltbeli eseményekre irányul, s kimaradni látszik belőle annak a lényeges dilemmának a mérlegelése, hogy miképpen hat a személy felelősségvállalására az értékrendje, gondolkodásmódja. Egyáltalán felméri-e előzetesen döntése, cselekvése következményeit? Tudatában van-e, reflektál-e gondolataira, szándékaira? Itt Milan Kundera fogalmazza meg tökéletesen a lényeget a felelösségvállalás esszenciájával kapcsolatban: „Hát nem éppen abban rejlik jóvátehetetlen büne, hogy nem tudta, hogy hitte?" (Kundera, 1992, 92. o.).

A felelösség viszonyokban, szereplők közötti kapcsolatokban áll, abban ragadható meg. Ha összekötjük a „felel” igét az egyéb jelentéstartalmakkal, kirajzolódik, hogy a felelősségnek három szereplöje van, azaz bármely felelősségi kapcsolatban legalább három dolog vagy személy érintett. Az alany felel valamiért/valakiért (tárgy), valakinek vagy valaminek (részeshatározó). Habár első pillantásra az efféle nyelvtani elemzés túlzónak, vagy akár feleslegesnek is tűnhet, a felelősség szervezeti kontextusban való vizsgálatához a releváns kérdések pont a „Ki?”, „Kiért/miért?” és „Kinek/minek?” kérdőszavakkal kezdődnek.

Azt, hogy az ,,alany” felelősséget vállal-e a „tárgyért”, erősen meghatározza kettőjük kapcsolata. Elvégre, ha közvetlen kapcsolatban állnak, előfordulhat, hogy az alany saját jólétét felelőssége tárgyának jóléte befolyásolja (például egy családtag boldogsága, szomorúsága meghatározza az egyén boldogságát, szomorúságát). Így tehát az alany és a tárgy viszonyában figyelmet kell szentelni a kapcsolati távolságnak, minőségnek és az esetleges rétegződésnek, mivel az észlelt kötelezettség ezeknek is függvénye (Eckley, 2015)

French (1979) elmélete az egyenlet másik oldalát támasztja alá. Véleménye szerint a számonkérhetőség személyek, személy és istenség, vagy személy és társadalmi normák közötti hatalmon alapuló kapcsolatot feltételez. A kötelék sokféleképpen létrejöhet, például szerződésen, felvételen, küldetésen keresztül. Általában a számonkérhetőség jogát külső szereplőnek delegálják, kivéve a morális felelősség esetén, mert ez alól nincs olyan személy, aki mentesülne.

Fenti, sokfelé nyitott gondolkodásunkba az integráció szándékával hívjuk meg Goodpaster és Matthews (1982) modelljét. A szerzők felelősségkategorizálása alapján a személyes felelősség fogalma három fő dimenziót ölel át:

- a felelősségre vonást,

- a szabálykövetést és

- a döntési helyzetben lévő szabad morális ítélőképességét.

Az első dimenzió a felelősségre vonást, a múltbeli tettekért való számonkérhetőséget foglalja magába morális és jogi tekintetben. A felelősségre vonhatósághoz itt meg kell határozni, hogy mi volt az adott személy szándéka, akarata, milyen mértékben vett részt a cselekedetben, és mi a tettének megfelelő jutalom vagy büntetés.

A felelősség másik eleme a társadalmi, közösségi normák követéséhez kapcsolódik (ilyenek a törvény által elöírt szabályok is).

A harmadik jelentésrész a döntéshozatalhoz köthető. Felelős döntéshozónak e tekintetben az a személy tekinthető, aki döntési helyzetet észlel, majd az általa azonosított adatok függvényében, értékei mentén dönt, ítél. Döntéseit így a racionalitás és a respektus határozza meg. A racionalitást Frankena (1980) megfogalmazása szerint „a tudatosság, az alternatívák és következmények számbavétele, a célok és szándékok körültekintő tisztázása és a végrehajtás részletei iránt tanúsított fegyelem" jellemzi. A respektus a döntés által befolyásolt résztvevők érdekeinek - mint a döntéshozó érdekével azonos relevanciával bíró döntési faktoroknak - figyelembevételét jelenti.

A racionalitással kapcsolatban mindenképpen ide kapcsolódik Simon (1982) korlátozott racionalitás elmélete, mely szerint ,a komplex problémák megfogalmazásában és megoldásában a valóságos helyzetekben előforduló problémák nagyságához viszonyítva az emberi elme kapacitása nagyon kicsi ahhoz, hogy az objektív racionalitás alapján oldhassuk meg ezeket a problémákat”. Ez elemzésünk tekintetében azért problematikus, mert jelentősen csökkenti a személy felelős döntéshozatali képességét, ha még az alternatívákat és azok következményeit sem tudja maradéktalanul felmérni. A másik nehézséget a respektus szubjektivitása jelenti. A személy moralitását befolyásolja értékrendje, világ- és emberképe, érettsége, szociális érzékenysége és egyéb személyiségjegyei. Fejlődése során erősen befolyásolják a környezeti hatások és a nevelési hatásrendszer (Bábosik, 2004). De ehhez hozzákapcsolódik az is, hogy a posztmodern társadalomban - a metanarratívák megkérdőjelezettsége miatt - hiányzik az egyetemes jó társadalmilag elfogadott értelmezése. A posztmodern fö mértéke a tolerancia, mely minden értéket, világnézetet és hiedelmet egyenlőnek tart, így tehát nincs olyan egyetemleges erkölcsi elvárás, mely jobb lenne a másiknál. Ebből következőleg a posztmodern rendszerben egyik ember erkölcse nem mérhető a másikéhoz (Kim et al., 2009). Mindeközben lelkiismeretünk teszi lehetővé a felelősség vállalását a bevégzett tettekért. „A lelkiismeret lelkünk törvénye, de felülmúlja lelkünket, parancsokat ad, jelzi a felelősséget és a kötelességet, a félelmet és a reményt" (Newman, 1969). Annyira mindenkinek jelen kell lennie önmaga számára, hogy meghallja és kövesse lelkiismerete hangját (Katekizmus, 1779; Szent Ágoston, 1989).

A személy döntése a morális dilemma jellemzőitől is függ. A kimenetelre hatással lehet a következmények mértéke, a társadalmi konszenzus, a következmények bekövetkezésének valószínűsége, időbeli elhelyezkedése, közelsége és koncentrációja (Ruiz-Palomina - Ruiz-Amaya, 2011). A döntéshez kötődő felelősség értelmezésének elemei szubjektívek, személyhez tartozók.

Az első fejezetben a felelősséggel a személy szintjén foglalkoztunk. Az 1. ábrán a fentiek alapján az egyéni felelősség dimenziói láthatóak; míg vízszintesen a felelős- 
ség kapcsolatrendszere manifesztálódik, függőlegesen a személyes felelősségre ható tényezők és a felelősség terü-

1. ábra

\section{A személyes felelősség dimenziói}

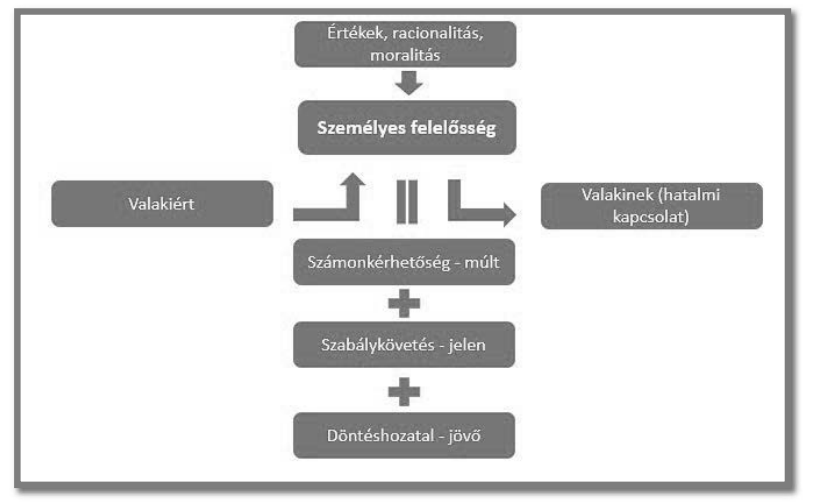

Forrás: saját szerkesztés

letei helyezkednek el.

A vízszintes tengelyen lévő kapcsolatrendszer teszi a felelősséget relevánssá és izgalmassá. Ha az alany döntései és cselekedetei nem vonnának magukkal másra (is) vonatkozó hatásokat, és az érintettek egymásnak ellentmondó érdekei nem hoznának létre feszültséget és dilemmákat, akkor nem kéne valaki felé elszámolni, vagyis nem is létezne a fogalom.

Függőlegesen jelennek meg a személy viselkedését, döntéseit befolyásoló értékek, kognitív képességek és a személyes erkölcs. Ez a tengely a felelősség területeinek időhöz kötöttségét is ábrázolja; bármely döntés és azt követő cselekvés hatása a jövőben alakul ki; az időbeli eltolódottság, valamint a jelen és a jövő közötti információs szakadék miatt az alany a cselekvés után kontrollt veszít a hatások felett. A jelenhez kapcsolódóan az alanynak lehetősége van a szabályokat felülvizsgálni, követni vagy ignorálni. A szabálykövetés kérdése természetesen egyben döntéshozatal is, még ha sok esetben nem is tudatos. A számonkérhetőség a múltban lezajló a döntés és cselekvés következtében létrejött hatásra vonatkozik. A kontrollvesztés itt is megmutatkozik abban, ahogy az alany szerepe a döntéshozatalhoz és a szabálykövetéshez képest aktívról passzív szerepre vált. Ezt a kapcsolati rendszeren alapuló modellt ültetjük most át szervezeti környezetbe.

\section{Felelősség a szervezetben}

A személyes felelősség keresése után most tehát a közösségi, többes felelősséget járjuk körül. Első körben szűkebb fókusszal gondolkodunk: az üzleti szervezetek képezik az elemzés tárgyát, majd kitágítjuk a horizontot, és tág értelemben vett (immár tetszőleges) szervezetekről írunk.

\section{Vállalati felelősségvállalás}

Mivel a felelősség ilyen hatalmas mértékben függ az adott embertől, nehéz és veszélyes nem fizikai, hanem jogi személyre értelmezni, pláne, mivel egy szervezet tényleges aktorai mégiscsak természetes személyek. Ebből a nehe- zen értelmezhetőségből következően szabályozni csak foghíjasan lehet a felelős vállalati viselkedést, szükségszerüen marad is mindig a törvény által nem lefedett terület. A gazdasági társaságok eddigi történelme során ezt ki is aknázták - például a korlátolt tagi felelősség elismerése nagymértékben hozzájárult a vállalakozási kedv élénkítéséhez (Bodzási, 2014).

A vállalati felelősségvállalás körüljárásához a hármas kapcsolati sémát vesszük alapul, vagyis a kérdés továbbra is az, hogy ki, kiért/miért és kinek/minek felel.

\section{Ki a felelös?}

„Az egyéni felelősségvállalás megkérdőjelezhetősége, majd részleges háttérbe szorulása a vállalati szférában a társasági alapítólevelek megjelenésével esik egybe. A társasági alapítólevelek lehetővé teszik, hogy magánszemélyek erőforrásaikat egyesítsék adott cél elérése érdekében, azonban a tevékenységük jogi felelőssége alól felmentést kapnak, ezt a már a létrejött jogi személy viseli" (Korten, 1996, p. 63.). Korten alapján nem kerülhető meg, hogy első körben a vállalatot értelmezzük felelősként. Arról azonban nem szabad megfeledkezni, hogy a szervezeti szabályokkal összhangban, vagy azokat megkerülve felelősen vagy felelőtlenül viselkedni végül csak természetes személy(ek) tud(nak), tehát habár a felszínen a vállalat egységes felelősségének a vizsgálata folyik, valójában azokat a tényezőket tárjuk fel, melyek a szervezeti tagok döntéseit és cselekvéseit befolyásolják.

Az elemzéshez szükség van a ,vállalati személyiség” megértésére. Ez alatt nem a marketingben divatos vállalati imázst értjük (bár ez a fogyasztók felé irányuló felelősségvállalás kapcsán is bejön), hanem egy cég szervezeti kultúráját, belső normáit és döntési mechanizmusait. A létrejött vállalat tevékenysége során olyan gyakorlatokat alakít ki, melyekkel csökkentheti a piac bizonytalanságaival kapcsolatos kockázatot, valamint növelheti a társaság nyereségét, de ezek már nem állnak feltétlenül a tulajdonosok kontrollja alatt (Korten, 1996).

French (1979) alapján a vállalat belső döntési mechanizmusa kétdimenziós: a struktúra egyfelől meghatározza a vállalati erőviszonyokat, másfelől ott a vállalati döntések szabályainak rendszere, mely általában a vállalati politika és kultúra része. A belső döntési rendszer megadja azt a munkatársi kört, mely a vállalati hatalom gyakorlására elvileg hívatott. Ennek révén ivódhatnak a vállalati tevékenységbe a valós személyek szándékai és cselekedetei, a prioritások, a választások révén. French (1979) szerint a belső döntési struktúra határozza meg a vállalat „személyiségjegyeit".

A vállalat tényleges személyiségének megértéséhez ugyanakkor nem elég a vállalati rendszer feltérképezése, szükség van a szervezeti kultúra átlátására is. Szervezeti szinten ez az, ami a felelősségvállalást értelmezi, illetve ösztönzi (Angus-Leppan et al., 2010). Az interpretatív szervezetelméleti paradigma szerint a vállalati valóságot nem lehet objektívnek tekinteni, a szervezeti valóságot, annak kialakulását és változását a szervezeti tagok cselekedetei és interakciói határozzák meg (Gelei, 2011).

„A szervezeti kultúra... a szervezet tagjai által elfoga- 
dott, közösen értelmezett elöfeltevések, értékek, meggyőződések, hiedelmek rendszere. Ezeket a szervezet tagjai érvényesnek fogadják el, követik, és az új tagoknak is átadják, mint a problémák megoldásának követendő mintáit, s mint kívánatos gondolkodási és magatartásmódot" (Bakacsi, 1998). A szervezeti kultúra szintjeinek meghatározásához a jéghegy metaforát alkalmazzuk, Schein (1996) kategóriarendszerével, mely az értékek és hiedelmek ré-

2. ábra

\section{A szervezeti kultúra szintjei}

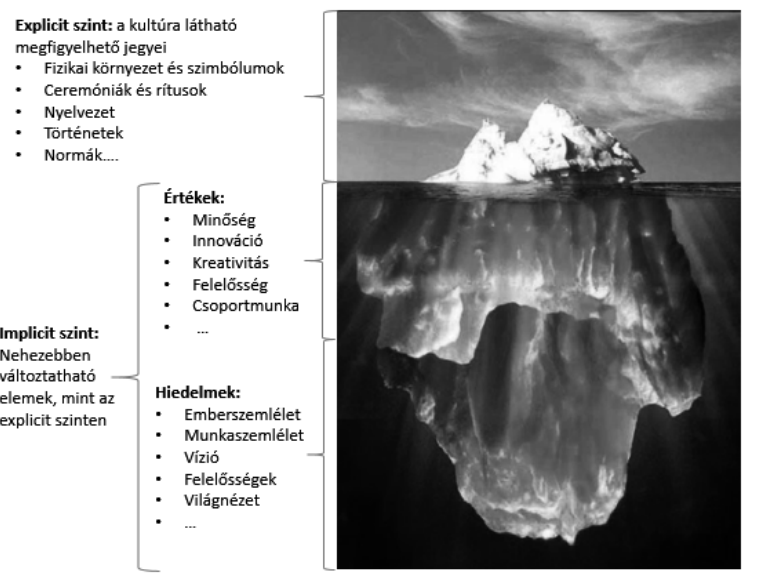

Forrás: saját szerkesztés Schein, 1996 alapján

szeire bontja a szervezeti kultúra implicit szintjét.

Exlipcit szinten, a jéghegy látható részében a nyelvezet, szakzsargon, szimbólumok, öltözködés és külső megjelenés mellett találhatók a szervezeti ceremóniák, szertartások, történetek, sztorik legendák, mítoszok. Míg az előbbiek inkább a kultúra elfogadására irányulnak, az utóbbiak felelősek azért, hogy a szervezet alapértékeit, az elvárt viselkedésmintázatot kommunikálják a dolgozók felé és példákkal megerősítsék bennük.

A felszín alatti első szinten található a felelősség szempontjából izgalmasabb értékek és rejtett előfeltevések szintje. Itt helyezkednek el a szervezet által elfogadott normák (amelyek a jó és rossz közös értelmezését képviselik), írott és íratlan szabályok. Fogalmazhatunk úgy is, hogy ezen a szinten találkozhatunk a vállalati önkontrollal és becsületességgel, ami például a menedzsment jutalmazási rendszereiben, a vezetés struktúrájában és a belső kontrollrendszerekben érhető tetten (Goodpaster - Matthews, 1982). Ugyanitt helyezkednek el az értékek is, melyek közös értelmezései annak, hogy mit szeretnének csinálni. A legalsó szint öleli fel a hiedelmeket, melyeknek a szervezeti tagok talán tudatában sincsenek.

Ahogy a 2. ábrán látható, személyes szinten a vezetők személyisége, kommunikációja jelentős motiváló tényezőként hat. A személyes és szervezeti szint a vezetők által kapcsolódik össze, mivel „,a vezetök müködtetik, a hősök (cégalapítók) teremtik a kultúrát" (Bakacsi, 2010, p. 203.). A vállalati vezetők saját értékeikkel átitatják a vállalatokat, befolyásolva azokat a vállalaton belüli döntési folyamatokat, melyek az érintettek érdekeinek figyelembevéte- léről szólnak (Christensen et al., 2014).

A legfelső vezetők viszont természetesen nem vezetik közvetlenül az összes szervezeti tagot az idők végezetéig (Greiner, 1972). Amikor a közvetlen irányítás ellehetetlenül, a túlélés érdekében delegálásra, az alkalmazottak döntési jogokkal való felruházására van szükség. A delegálással mint a vállalatok mindennapi müködésének egyik alapvető elvárásával kapcsolatban lényeges Battles (2005, p. 39.) kitétele, mely szerint, habár a feladat végrehajtása másra ruházódik át, a munka elvégzéséért és annak helyességéért való felelősség nem. Ezáltal kijelenthető, hogy a vállalati vezetők felelősek a ranglétrában alattuk dolgozó összes munkavállaló döntéseiért és cselekedeteiért.

A döntési felelősséget ugyanakkor általában nem személyhez, hanem pozícióhoz kötik a vállalatok. Ez releváns a témában, mert a globalizáció következtében a különböző szervezeti szereplők rengetegszer hoznak meg olyan döntéseket, melyeknek hatása az érintettek olyan körére vonatkozik, melyekkel a döntéshozónak nincs kapcsolata. Söt, sokszor még csak nem is egy földrészen élnek, így a döntéshozó nem is szembesül döntésének e szereplőkre vonatkozó hatásával. Emellett problematikus az is, hogy az általános szervezeti fluktuációnak köszönhetöen olyasvalaki döntéséért, cselekedetéért kéne felelni, aki már elhagyta a vállalatot vagy az adott pozíciót, így ő már (legalábbis szervezeti keretek között) nem számonkérhető.

A dötéshozók eltávolodása a következményektől és a következményeket viselőktől azonban nem kizárólag vállalati jelenség. A globalizációval a gazdaság minél hatékonyabb müködése érdekében a piacokon a szereplök közötti tranzakciók során gyakori a kapcsolatok rétegződése. A másik oldalon lévő szereplők névtelensége, felcserélhetősége és távolsága közömbösséget szül. Így a tranzakció „,csak az üzletről szól”, amiben az egyén a föáramú közgazdaságtan emberszemlélete alapján önérdekérvényesítő, és kizárólag a szerződés által kötelezett (Eckley, 2015). A hatékonyság természetesen jelentős nevesített előny lehet - a problémát az szüli, hogy csak az elönyöknek vagyunk tudatában. Míg a tranzakciók szereplőinek ilyen jellegü szemlélete negatív hatással van a kapcsolatok minőségére, lényegében a fent bemutatott folyamat következménye, hogy a másik oldali szereplö tárgyiasulhat (és tárgyiasul is) a résztvevők szemében.

\section{Kiért/miért felel a vállalat?}

Habár a jelen elemzésben vizsgált vállalati felelősség nem egyezik meg a vállalati társadalmi felelösség (CSR - Corporate Social Responsiblity) elméletével, a fenti kérdésröl szóló szakmai vita bemutatásához segítségünkre lesznek a CSR-szakirodalom egyes szemelvényei, valamint Carroll (1991) vállalati felelősségről alkotott csoportosítása.

A vállalati felelősség terjedelméről való vita kezdetét sokszor kötik a híres 1919-es Dodge versus Ford bírósági ügyben hozott határozathoz, mikor a Dodge fivérek beperelték Henry Fordot, amiért az eredményt a vállalatba akarta visszaforgatni, ahelyett, hogy osztalékként kifizette volna. Ford érvelése a következő volt: „Arra törekszem, hogy még több embert tudjak alkalmazni, és ezzel több 
embert bevonjak az ipari rendszerünk előnyeinek élvezetébe, hogy segítsek nekik felépíteni az életüket és otthonukat. Ennek érdekében a profit nagy részét visszaforgatjuk az üzletbe" (Greenfield, 2015, p. 30.). A Michigani Legfelsőbb Bíróság, amely megijedt az érvek túlzott szocialista felhangjától, végül a következőképp határozott, ezzel hosszú évekre erősen lekorlátozva a vállalat és vezetőinek kötelezettségi körét: „A gazdasági vállalatokat elsősorban a részvényesek profitjának növelésére kell létrehozni és múködtetni. Az igazgatók hatalmát pedig egyazon célra kell felhasználni. Az igazgatói hatalom arra terjed ki, hogy megválassza a cél eléréséhez szükséges eszközöket, a célon való változtatás viszont kívül esik hatókörén, amennyiben ez nyereség csökkenéséhez vagy az osztalék visszatartásához vezet" (Greenfield, 2015, p. 30.). Greenfield ezt az amerikai társasági jog eredendő bünének nevezi.

Ezzel az általános nézettel összerendelve a korlátolt felelősség lehetőségét, vészjóslóvá válik a gazdasági rendszer. A probléma azonnal felmerül, ha figyelembe veszszük, hogy a csődeljárások során, ha a vállalat minden eszközét értékesítették, senkinek sem kell megfizetni a pórul járt hitelezőket, beszállítókat, fogyasztókat. A magyar szabályozás ez ellen próbál fellépni a felelősségátvitel intézményével és a felelös vállalatvezetés elvével. Az elöbbi a tulajdonost, az utóbbi a vezetőt kötelezi a kárpótlásra, amennyiben bizonyítható, hogy visszaélés történt.

Nem óhajtunk egyoldaúan érvelni, beismerjük, a korlátolt felelősségnek természetesen jelentős előnyei vannak. Egyrészt a részvényeseknek a vállalat számára nyújtott tőkéje által az akkumulált vagyonnal a vállalat könyebben termel értéket és munkahelyeket, mintha ugyanezeket az anyagi erőforrásokat szeparáltan használnák fel a tulajdonosok. Emellett a korlátolt felelősségnek köszönhetően jöhettek létre a tőkepiacok. A korlátolt felelősségnek köszönhetően ugyanis a befeketetési döntések meghozatalakor nincs szükség a tulajdonosok egyenkénti ellenőrzésére, elég a vállalatot átvizsgálni, melyben a részvényeseknek csak standardizált és csökkentett kockázattal kell számolni (Schulter, 2000).

A vállalati társadalmi felelősség elméletének megjelenéséig, 1950-ig, tehát a közvéleményben a vállalatok egyetlen felelőssége az anyagi megtérülés biztosítása volt a részvényesek számára - és még mindig nagyon erős ez az eredeti felfogás. Köszönhető mindez annak is, hogy neves közgazdászok, köztük a Nobel-díjas Milton Friedman megtámadták a CSR létjogosultságát:

„A társadalmi felelősség elve egy alapvetően felforgató elmélet egy szabad társadalomban, ahol a vállalatoknak egy társadalmi felelösségük (azaz feladatuk) van: a profit növelésére irányuló tevékenységet végezni és erre használni erőforrásaikat, egészen addig, amíg betartják a játékszabályokat, azaz csalás és megtévesztés nélkül vesznek részt a nyílt és szabad versenyben" (Friedman, 1970).

Friedman állítása ingatag, hisz a vállalatok társadalmi felelőssége egyértelmüen azonosítható a számukra nélkülözhetetlen érintettekre és erőforrásokra gyakorolt hatásukon keresztül. Hatalmuk (gazdasági erőterük) és az érintetteikre tett hatásuk sokszor olyan mértékü, hogy nem szentesíthető bármely gazdasági döntésük a profit- generálás céljával. Porter és Kramer (2011, p. 64.) a következőképpen foglalták össze a problémát: „A vállalatok továbbra is szűkösen definiálják az értékteremtést: rövid távú pénzügyi teljesítményüket optimalizálják, és figyelmen kívül hagyják azokat a tényeket, melyek hosszú távú sikerüket határoznák meg. Hogyan másként kerülhetné el a figyelmüket a fogyasztók jóléte, az üzletük számára létfontosságú erőforrások kimerülése, a kulcsbeszállítók életképessége és azokban az országokban lévő gazdasági feszültség, ahol termelnek és értékesítenek? Mi más igazolná azt, hogy a vállalatok a verseny kihívásainak fenntartható megoldását a tevékenység alacsonyabb munkaerővel bíró országokba való áttelepítésében látják?” Ebben a meglátásban a felelős vállalati viselkedés még mindig nem öncélú, hanem a hosszú távú vállalati érdekek által legitimált, vagyis önérdek mozgatja; Porter és Kramer megfogalmazásából azonban legalább az olvasó levonhatja azt az esszenciális következtetést, hogy a rendszer (még ha a globalizáció következtében a piacok rendkívül meg is nőttek) nem végtelen türőképességü.

Carroll (1991) társadalmi felelősségvállalásról alkotott piramisa szerint a vállalatnak gazdasági, jogi, erkölcsi és

\section{3. ábra}

\section{A CSR piramisa}

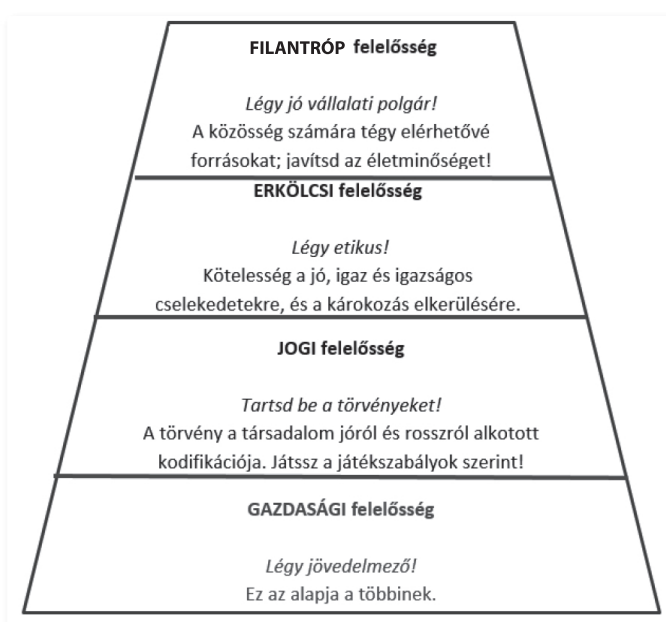

Forrás: Carroll, 1991

filantróp felelősségei vannak (lásd a 3. ábrát.)

A gazdasági és jogi felelősség a vállalati felelősségvállalás azon részei, melyek a működőképesség előfeltételei, vagyis anélkül, hogy a vállalat ezeknek megfelelne, hoszszú távon nem fenntartható. Ha a vállalat érintettjeinek körét nézzük, gazdaságilag elsősorban a belső érintettekért vállal felelősséget; a tulajdonosok pénzéért és a munkavállalók megélhetéséért, s egyben mindazokért, akikkel szemben valamely kötelezettséget vállalt, ők a hitelezők, a szállítók és a fogyasztók. A szervezet jogi felelősséget a müködéséért a szabályozó hatóságok és a partnerek előtt vállal.

A vállalatok erkölcsi felelőssége értelmezésünkben magában foglalja a CSR piramis első két szintjét, azonban túl is mutat ezeken. Az üzleti és emberi jogokra vonatkozó irányadó ENSZ-alapelvek szerint a vállalatok tevékenysé- 
gük során felelősek az emberi jogok tiszteletben tartásáért, még akkor is, ha erre törvényileg nincsenek kötelezve. Erkölcsileg felelősségük minden érintettre kiterjed (beleértve a természeti környezetet), akivel kapcsolatba lépnek.

A filantróp felelősség kutatásával túllépünk a vállalat saját üzleti tevékenységén. Itt érünk el a társadalmi felelősséghez, amit úgy is jellemezhetnénk, hogy ,extra felelősség”, ugyanis a piramis legfelsőbb szintje a vállalat a vele kapcsolatban lévő közösségek felé vállalt felelősséget jelképezi. Azt, hogy mit és milyen mértékben ad vissza a társadalomnak, teljesen a saját döntésére van bízva, vagyis senki nem fogja felelötlennek beállítani, ha ennek nem felel meg. Azért nem érdemes a filantróp felelősség értelmezését elválasztani az általános felelősségétől, mert nem lehet egy szervezet ,jó vállalati polgár” anélkül, hogy az első három szintet teljesítené. A filantróp felelősség „hátránya", hogy könnyen felhasználható a befektetői és fogyasztói vélemény manipulálására (ezt hívják az angol terminussal ,greenwashingnak”), az ilyen adományok a vállalatok számára ugyan nem járnak nagy lemondással, de a társadalom, társadalmi csoportok számára komoly segítséget jelenthetnek. Probléma olyankor merül fel, ha ezt a cég kizárólag saját imázsának javítására használja. Éppen ezért, ha felelősnek akarunk minősíteni egy vállalatot, mind a négy szinten meg kell vizsgálni, hogyan viszonyul az érintettek érdekeihez, függetlenül attól, milyen kapcsolati távolságban áll tőlük. A legfontosabb mégis az első három szintnek - a gazdasági, jogi és erkölcsi felelősségnek - való megfelelés. Ha filantropikus tevékenységet is végez, nyilván örvendetes, de ezt ne az előző háromban felmerülő problémáinak elfedéséért tegye.

\section{Kinek vagy minek kell elszámolniuk a vállalatoknak?}

Ezen a ponton térjünk vissza French (1979) elméletéhez, mely szerint az elszámoltathatóság hatalmon alapuló kapcsolatot feltételez. A hatalom definiálásához Bakacsi (1998, p. 156.) meghatározását használjuk fel: „A hatalom képesség arra, hogy más szereplőket befolyásoljon saját céljai megvalósítására. A hatalom jó lehetôség mások magatartásának befolyásolására, az események megváltoztatására, az ellenállás legyőzésére. ... a hatalom mögött mindig függést feltételezhetünk."

A fentiek alapján olyan külső személy vagy személyek csoportja, melynek általános értelemben a legnagyobb hatalma van a vállalat felett (vagyis akiktől bármilyen viszonyban is függ a vállalat, bár ez a függés lehet kölcsönös): az állam és a fogyasztók. Elvégre a vállalat az államtól születik, tőle kapja az engedélyt a müködésre, és létezését a cégjegyzékbe vétellel az állam legitimizálja, működésének , játékszabályait” ő irányítja. A fogyasztóktól való függés pedig annak köszönhető, hogy a vállalatot a fogyasztók ,éltetik”, ők tartják müködésben.

A ,születés után” ugyanakkor a gyerek könnyen a szülő fejére tud nőni. Ha csak megnézzük, hogyan alakult 2014-ben az egyes államok GDP-je, illetve a legnagyobb vállalatok jövedelme, azt láthatjuk, hogy a világ legnagyobb bevételével rendelkező vállalatát, a Wal-Mart Stores-t (485.65 Mrd USD) mindössze 27 állam előzte meg
GDP-jével. Így, míg az Egyesült Államoknak (17,418.9 Mrd USD) nagyobb gazdasági erőtere van az összes multinacionális vállalatnál, addig Magyarországot (amely a 137.1 Mrd USD GDP-ével az 57. leggazdagabb ország) 20 vállalat szorítja maga mögé a vagyonával. A vállalatok jelentősége pedig valószínüleg csak nőni fog. Korten (1996, p. 87.) a következőképp figyelmeztet a jelenségre: „A szabályozatlan piacok valós világában a sikeres szereplők egyre nőnek, és a megnövekedett gazdasági hatalmukat arra használják, hogy kizárják vagy kivásárolják a gyengébb szereplőket, s ezzel a piac mind nagyobb hányada felett szerezzenek ellenőrzést."

Kérdésessé válik tehát, hogy a táguló vállalati erőterek mellett hogyan állnak helyt az országok végrehajtó szervezetei. De még ha az egyik állam sikeresen is tevékenykedik e téren, a vállalatoknak állandóan rendelkezésére áll egy kiskapu; lehetőségük van egyes tevékenységeket vagy a teljes termelést olyan államba telepíteni, ahol a szabályozások gyengébbek, esetleg a lakosok rá vannak szorulva a cég által generált munkahelyekre, ezért elhanyagolható kérdéssé válik, hogy az így teremtett állások kizsákmányolják a dolgozókat. Kiszervezés révén beszállítókkal is exportálhatják a szabályokba ütköző magatartást. A cégeknek tehát van mozgásterük, amikor a játékszabályok megválasztásáról van szó. Az államok multinacionális vállalatokkal szembeni erötlenségének egyik nyoma a civil szerveződések és mozgalmak elterjedése. Ez jelzi, hogy nincs olyan hatékony állami vagy globális szervezet, ami e vállalatok tevékenységét áthatóan és egységesen ellenőrizni tudná (Tarró, 2012).

A fogyasztók szempontjából elsődleges probléma, hogy igazi hatalmi erejük csak együtt lenne, viszont mivel rendkívül heterogén csoportról beszélünk, amelynek tagjai nem azonos célokkal, értékekkel rendelkeznek, és rendkívül különbözőféleképpen reagálnak, így a fogyasztók hatalmi ereje feldarabolodótt. Egyszerűen képtelenség, hogy minden fogyasztó minden termékröl és szolgáltatásról beszerezzen minden információt, amire szüksége van „hatalmi döntésének” (vásárlás vagy nem vásárlás) következetes és felelősségteljes meghozatalához. Az információhiányból következően pedig egyszerüen manipulálhatóak.

A vállalati felelősség felvállalásával van még egy probléma, amennyiben annak mozgatórugója a fogyasztók vállalatról alkotott véleménye. Ez pedig az, hogy hosszú távú szemléletet feltételez, míg a cégek várható élettartama csökken. Amerikában a Standard \& Poor's 500-as index cégeinek élettartama 67 évről 15 évre esett vissza 1920-tól napjainkig. A helyzet pedig Európában, vagy a családi hagyományos cégek Mekkájában, Japánban sem kedvezőbb. A Stratix Group (de Rooij, 1996) kutatása alapján ezeken a kontinenseken a cégek átlagéletkora 12,5 év. Valószínüleg a felmérés óta elmúlt 20 évben a helyzet nem sokat javult, sőt, ez a tény még ijesztőbbé válik, ha figyelembe vesszük, hogy a felmérés még a digitális forradalom és az egyik napról másikra sikeressé váló startupok világa előtt készült.

A probléma tehát az, hogy míg a nagy nemzetközi vállalatok erőtere egyre jobban tágul, nincs olyan eszköz 
vagy csoport, ami igazán hatékonyan egyensúlyozhatná ezt a növekedést, mivel a nagyvállalatok (legalábbis rövid távon) egyre kevésbé függnek azoktól a csoportoktól, melyeknek meg kell, hogy feleljenek.

A 4. ábrán látható, hogy a felelősség fogalmának modelljét miként helyeztük vállalati kontextusba. Összegezve az eddigieket: a vállalati felelősséget - a személyeshez hasonlóan - csak a hármas kapcsolati rendszerben tudjuk értelmezni. Egyrészt meg kell érteni a vállalatot mint cselekvőt: a szervezeti kultúra alapján mit jelent itt a felelős viselkedés; ezt milyen rendszerben kérik számon, ha számon kérik; milyen szabályozással próbálják irányítani, illetve mi alapján és mely tagok hozzák meg a döntéseket, milyen elismerési szabályok vannak érvényben.

4. ábra

A vállalati felelősség dimenziói

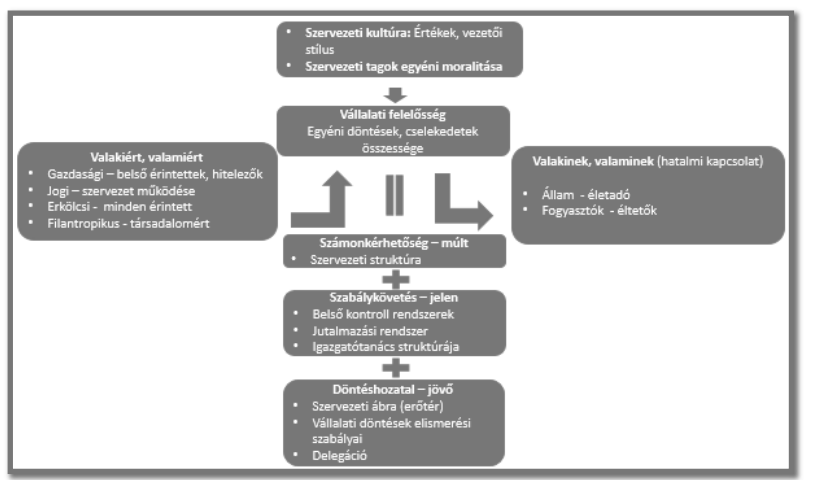

Forrás: saját szerkesztés

A kapcsolati egyenlet baloldalával kapcsolatban fontos: az, hogy milyen érintettek érdekeiért tesszük felelössé a vállalatot, függ attól, hogy mennyire bontjuk le a vállalat velük való kapcsolatrendszerét (pl. valóban felel-e a vállalat beszállítóinak munkakörülményeiért?). Ha az ábrán kiemelt csoportokat megfigyeljük, ez Carroll piramisa szintjeinek fejlődésében is visszatükröződik, ahogy egyre távolodunk a vállalat közvetlen érintettjeitől - bár az első három „lépcsőfok” az alapelvárást tükrözi a vállalattal szemben. Ha ezek megsértésére fény derül, az rossz szín-

5. ábra

A vállalati felelősségi rendszer és problémás területei

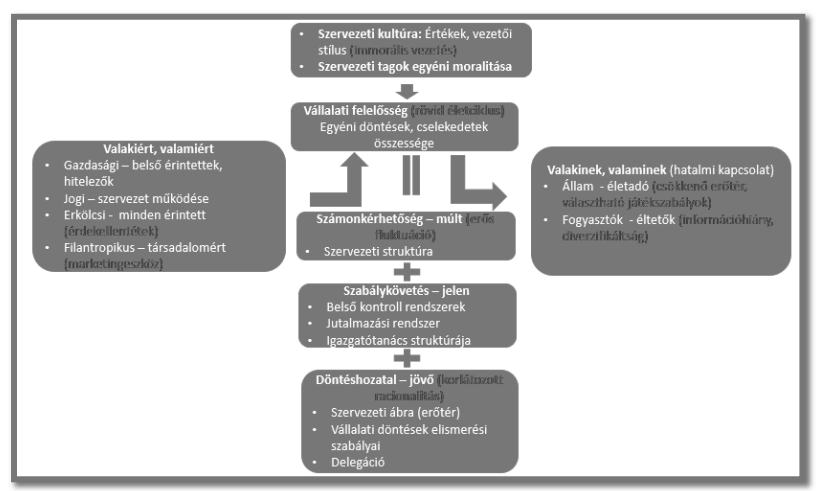

Forrás: saját szerkesztés ben tünteti fel a vállalatot.

Az egyenlet jobb oldalán azok a szereplők jelennek meg, melyeknek hatalmában áll a vállalati tevékenységet befolyásolni. Általánosan egy vállalat leginkább az állammal és a fogyasztókkal áll erős függelmi viszonyban, a legnagyobb multikkal szemben azonban megkérdőjelezhetö, mennyire tudja ez a két csoport véghezvinni az akaratát.

A fejezet során említett problémákat az 5. ábra kiemelten összegzi. Ebböl kitünik, hogy a modell minden dimenzióján lehetséges olyan rést találni, ami a szervezeti felelősségteljes viselkedést hátráltatja. A rések keletkezését két tény okozza: a kapcsolati rendszer átláthatatlansága, valamint az alany változékonysága.

A kapcsolati rendszerben mozogva szervezeti szinten a szerepek észlelését, azonosítását rendkívül megnehezíti a szereplők magas száma. A nem érzékelt felelősség magában hordozza azt a veszélyt, hogy bizonyos szereplők érdekei figyelmen kívül maradnak a döntési helyzetekben, tehát sérül a kapcsolati egyenlet bal oldala. Ezt csak tetézi az, hogy az észlelt érintettek észlelt érdekei is ellentmondhatnak egymásnak. Az átláthatatlanság leginkább a szervezeti felelősség erkölcsi szintjére jelent veszélyt, és a döntéshozatalt nehezíti meg.

Az alany változékonysága a vállalatok átlagos életciklusának csökkenő tendenciájából, a szervezeteken belüli fluktuációból, illetve a területi mobilitásból fakadó játékszabály változtatási lehetőségéből áll. Az alany változékonyságával csökkenti annak a hatalmát, akinek felelnie kellene, és ezzel a rendszerben a számonkérhetőség kérdőjeleződik meg.

A felelösségi kapcsolati rendszer mindkét irányban való sérültsége mellett nem meglepőek az elmúlt időszak köztudatba került vállalati túlkapásai, melyek között megtalálható a gyermekmunka, a rabszolgaság, a kényszermunka, a dolgozók és a források kizsákmányolása, de az emberi egészségre káros kemikáliák használata is, akár anélkül, hogy a munkások védőruhát kapnának. Előfordul a polgárháború és a fegyverkereskedelem támogatása is (Werner et al., 2006).

\section{A modell kiterjeszthetősége nem üzleti szervezetekre}

A fentiekben az üzleti szervezetek (gazdasági társaságok) felelősségének értelmezésére és az alapvető problémák azonosítására tettünk kísérletet. Ezen alfejezetben a szervezetek világának másik két szektorával: a közszolgálati (,public”) és a nonprofit (,civil”) szektorral foglalkozunk, modellünket integráló szándékkal gondolva tovább.

\section{Ki felelös?}

Veszprémi Bernadett doktori kutatását és disszertációját szentelte a közszolgálati szervezetekben dolgozó munkatársak felelősségének (Veszprémi, 2010.). A „közszolgálati alkalmazottak" olyan szervezeteknél dolgoznak, amelyeket részben vagy egészben a „köz”, a „társadalom”, az állam vagy az önkormányzat tart fenn. Ezek a szervezetek a köz érdekében feladatokat látnak el, közszolgáltatást nyújtanak, állami alapfunkciókat valósítanak meg. 
A „közszolgálat” meghatározása ugyanakkor nem egységes. „,... nemzetközi szinten sem találkozunk egységes fogalommal. Magyarországon sem csak egy elnevezést használunk azokra, akiket a közszolgálathoz tartozónak tekintünk. Beszélhetünk köztisztviselőkröl, közalkalmazottakról és szolgálati jogviszonyban állókról” - fogalmaz Veszprémi (2010, p. 20.).

A ,nonprofit szektor” határainak, egyben a szektor szervezeteiben dolgozók alapjellemzőinek kijelöléséhez felhasznált három kulcsfontosságú kritérium Kuti (1998, p. 7-8.) szerint a következö:

- a profitszétosztás tilalma,

- működési autonómia és szervezeti elkülönülés a kormányzati szektortól (nem zárja ki, hogy közfeladatokat vállaljanak át, kormányzati megrendeléseket kapjanak és állami támogatásokban részesüljenek, de sem jogilag, sem intézményesen nem tartozhatnak az állami szférába),

• intézményesültség, önálló jogi személyiség.

A közhasznúság, a közjó szolgálata alapvetés, de nem állami forrásokból. A nonprofit szervezetek alapvető definíciós sajátja még az önkéntesség, a jótékonyság és a civil kezdeményezések léte.

A szűken vett megfogalmazás szerint a „közszolgálati felelősség" alapvetően a szabályok, szabályzatok, elvek és célkitüzések betartását, figyelembevételét jelenti. „Ennek eszközei többek között a megfelelő tájékoztatás, a rendszeres információcsere, a továbbképzés biztosítása, a folyamatos ellenőrzés, a visszajelzésekre, problémákra való gyorsreagálás, a minősítés és a teljesítményértékelés" (Veszprémi, 2010, p. 42.). „A köztisztviselökre vonatkozó feladat- és hatásköri rendszer, ellátásuk, gyakorlásuk módja jogszabályokban van rögzítve. Felelősségröl ezek nem teljesítése, megtagadása esetén beszélhetünk, ami a jogi keretek miatt egyben jogsértésnek minősül. A jog párja a kötelezettség, az pedig magában hordozza a felelősséget" - teszi hozzá.

Bár a szervezetek küldetése és alapcélrendszere eltérő, nyilvánvaló: az üzleti szervezetek szervezeti felelösségéhez kapcsolódó gondolatok a közszolgálati és a nonprofitszektor szervezeteinél is érvényesek.

\section{Kiért/miért felel a szervezet?}

A közszolgálati és nonprofit szervezetek müködését bemutató közkeletű eszköz, a teljesítmény $4 \mathrm{E}$ koncepciója (lásd Kiss-Révész, 2011, p. 9.; Bouckaert, 2002) látható a 6. ábrán.

Itt a szervezeti felelősség szempontjából a gazdasági társaságoknál kifejtettekhez képest hangsúlyozottabban jelenik meg a hatás és a méltányosság: milyen eredmények jelentkeznek a konkrét szervezeti outputok hatásaként (outcome), a létrejött termék vagy szolgáltatás a szervezetet elhagyva milyen lépéseken keresztül, milyen hatást gyakorol a társadalomban, s ezért ki és miképpen vállal felelösséget (vö. Kiss-Révész, 2011, p. 9.).

Clements és Bowrey (2010) a közszolgálati szervezetek értéklánca elemzésének keretében azonosította és ér-
6. ábra

A közszolgálati szervezetek 4E modellje

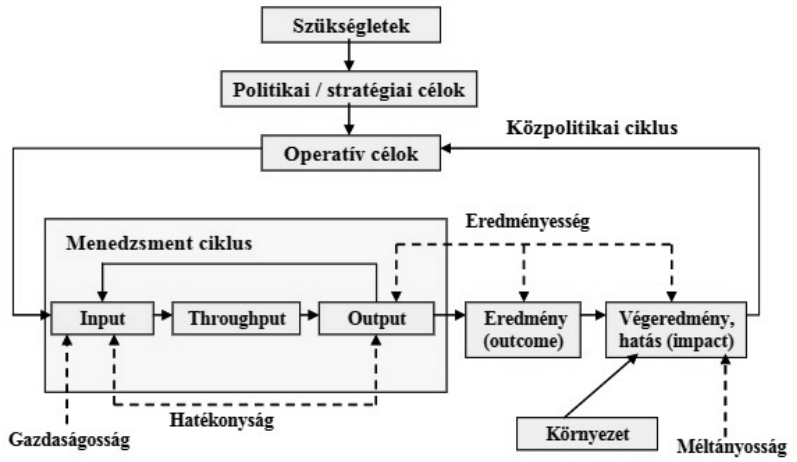

Forrás: Kiss-Révész, 2011, p. 9.

7. ábra

A közszolgálati szervezetek értéklánca - célok, irányok és CSR-beszámolók

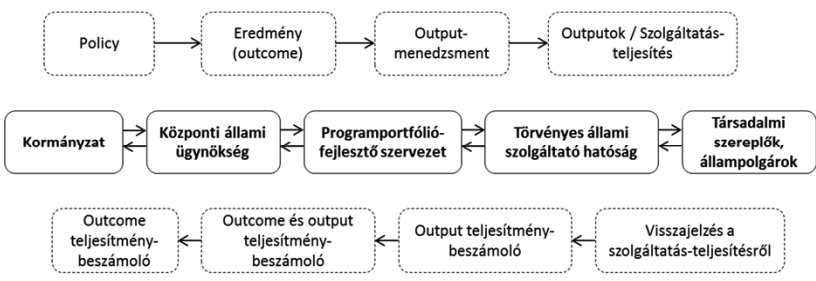

tékelte a szektor tevékenységét.

\section{A 7. ábrán bemutatott modelljük fö elemei:}

- a kormányzat, mely a teljesítendő szolgáltatások meghatározója, ,eredete”,

- a központi ügynökségek, melyek rendszerszemléletű (holisztikus) tanácsokat adnak a kormányzat számára a policy- és programfejlesztéshez,

- a program(portfólió)fejlesztő szervezetek, melyek a programokat ténylegesen kidolgozzák,

- a szolgáltató hatóságok, melyek keretében/elrendelésére a szolgáltatásokat teljesítik,

- a társadalmi szereplők, akik a szolgáltatások címzettjei.

A balról jobbra tartó nyilak a termékek/szolgáltatások áramlását mutatják az értékláncban elöre, míg a jobbról balra haladó nyilak a szervezetek között (visszafelé) áramló információkat jelzik.

A szerzők kutatásukban arra jutottak, hogy a szereplők a gyakorlatban jellemzően egy-egy szakaszra, szegmensre összpontosítanak, miközben a teljes értéklánc holisztikus szemléletére lenne szükség. A társadalmi felelősség „...immár nem egy-egy szervezet saját tulajdona, hanem egyre inkább felöleli a teljes értékláncot" (2009, p. 77.). Lám: a közszolgálat küldetéses gyakorlása és egyben mások támogatása áll e szervezetek felelősségének középpontjában.

Nyilvánvalóan ezzel egyező alapcél határozható meg a nonprofit szervezetek esetében is: a nonprofit szervezetek 
és a társadalmi, közösségi felelősségvállalás egzisztenciálisan függnek össze. „A jótékonyságra, öntevékenységre és önkéntes munkára a társadalomnak a szükségletek kielégítése, a szociális problémák kezelése, maguknak az állampolgároknak pedig saját belső egyensúlyuk és a társadalomban elfoglalt helyük megszilárdítása érdekében van szükségük. Ebből elméletben nemcsak az következik, hogy a nonprofit jelenségnek a modern társadalomban rendkívül kiterjedtnek kell lennie, hanem az is, hogy kiterjedtsége bizonyos értelemben a társadalom egészségének mutatójaként is felfogható. A közösségi kezdeményezések magas arányából szoros és szerteágazó társadalmi kapcsolatokra, az állampolgári felelősségérzet és szolidaritás erősségére, az egyének szilárd társadalmi beágyazottságára lehet következtetni. Alacsony szintje éppen ellenkezőleg - súlyos problémákra, a társadalom atomizáltságára, s az egyének ezzel szorosan összefüggő talajvesztésére utal" (Kuti, 1998, p. 106.).

\section{Kinek vagy minek kell elszámolniuk a szervezeteknek?}

A közszolgálati és nonprofit szervezetek definíciójukból, önmeghatározásukból, létükből eredően felerősítik, középre helyezik tehát a felelősségvállalás témáját - egyéni és közösségi szinten egyaránt (Kuti 1998, p. 92.; Siegel Yancey, 1992, p. 15. alapján):

- eszközül szolgálnak a különféle komplex társadalmi szükségletek kifejezéséhez és aktív kezeléséhez,

- az embereket arra ösztönzik, hogy a társadalmi élet minden területén állampolgárokként viselkedjenek, ne hajoljanak meg az államhatalom előtt, ne hagyatkozzanak annak jóindulatára,

- védelmezik és erősítik a pluralizmust és a társadalmi sokszínüséget, így a kulturális, etnikai, vallási, nyelvi (és egyéb) identitástudatot is,

- létrehozzák azokat a mechanizmusokat, amelyek segítségével a kormány és a piac a közösség által elle-

\section{A nonprofit szervezetek társadalmi/közösségi felelősségvállalásának modellje}

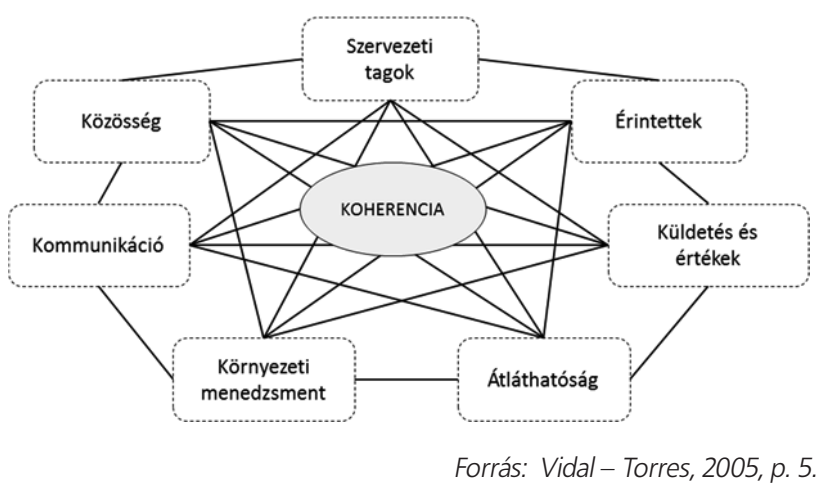

nőrizhető és felelősségre vonható.

Lényeges ugyanakkor, hogy a számonkérhetőség - szabálykövetés - döntési mechanizmusok hármas szem- pontrendszere mentén ugyanúgy sebezhetők, mint bármelyik más szervezet. „A nyilvántartott alapítványok és egyesületek jelentékeny része nem egyéb, mint az adóelkerülés eszköze; egy másik, szintén számottevő hányada ugyan fontos társadalmi funkciókat tölt be, de tevékenységével etikai normákat (sőt, gyakorta jogi elöírásokat is) sért. Ennek a helyzetnek a kialakulása nem független a társadalom általános állapotától, de a fenyegető morális válság megelőzésében magának a nonprofit szektornak is nagy a felelőssége" - írja Kuti Éva (Kuti, 1998, p. 120.).

A 8. ábrán látható Vidal - Torres (2005) modell e gondolatok mentén jól összegzi a nonprofit szervezetek felelősségvállalásának legfontosabb elemeit.

A közszolgálati szervezetek céljait, müködését és finanszírozását alapvetően az állam (a központi költségvetés, illetve a helyi önkormányzat) határozza meg. A Világbank egy 2002-ben megjelentetett tanulmánya kétdimenziós modellel keretezi és kutatja a szervezeti felelősség, ehhez kapcsolódva a felelősség szempontjából a közszolgálati szektor lehetséges és szükséges szerepvállalását (Fox - Ward - Howard, 2002). A modellt az 1. táblázat mutatja be.

Az első dimenzióban a szerzők a szektor négy alapfunkcióját, szerepét helyezték el:

- normatív-elöíró szerep (mandating),

- kezdeményező-facilitáló szerep (facilitating),

- kapcsolatépítő-partneri szerep (partnering),

- jóváhagyó-érvényesítő szerep (endorsing).

A másik dimenzióban megneveztek tíz kiemelt témát, melyek relevánsnak és hasznosnak tüntek e közszolgálati szerepek értelmezéséhez, mélyítéséhez, majd feltöltötték példákkal a cellákat. A modell így láttatja e szervezetek komplex felelősségét, továbbértelmezve 5. ábránk bal oldalát („Valakiért, valamiért”): ezek szerint hangsúlyozottan felelősek mások felelősségének növekedéséért is.

Rövid utazást téve a közszolgálati és a nonprofit szervezetek világába, úgy ítéljük meg, hogy a 4. ábrán bemutatott felelősségmodellünk, illetve ennek kihívásokkal gazdagított, bővített változata tetszőleges szervezetre kiterjeszthetö.

\section{A továbblépés szándékai és útjai}

„A természetes erkölcsi törvény tulajdonképpen megfogalmazás nélkül van érvényben. A természetes erkölcsi törvény az értelem törvénye. Alapja abban a tényben rejlik, hogy az ember, ez az értelmes lény, nem egyszerüen ösztönösen sodródik a célja felé, hanem útjait szabad felelősséggel járja” (Veres, 1993, p. 16.). A „felelősség” lényege a „felel” szóéval kapcsolatos: ha felelős vagyok, készen állok a feleletre, a válaszadásra. Nagykorúságunk lényeges jele e felelösségtudat.

A felelősségvállalás komplex jelenség. Egyfelől nagyon személyes, emberi: a világban való jelenlétünkhöz kapcsolódik, mindennapos, de egzisztenciálisan bekötött, állandó értékviszonyítást megkívánó ügy. Belőlünk indul, 
Közszolgálati szervezetek tevékenységének jellemzése CSR szempontból

\begin{tabular}{|c|c|c|c|c|}
\hline $\begin{array}{l}\text { Közszektorban betöltött } \\
\text { szerep }\end{array}$ & $\begin{array}{c}\text { Normatív-elöíró szerep } \\
\text { (mandating) }\end{array}$ & \begin{tabular}{|c|}
$\begin{array}{c}\text { Kezdeményező-facilitáló szerep } \\
\text { (facilitating) }\end{array}$ \\
\end{tabular} & $\begin{array}{l}\text { Kapcsolatépítö-partneri } \\
\text { szerep (partnering) }\end{array}$ & \begin{tabular}{|c|}
$\begin{array}{c}\text { Jóváhagyó-érvényesítő } \\
\text { szerep (endorsing) }\end{array}$ \\
\end{tabular} \\
\hline \multicolumn{5}{|c|}{ TÉMA } \\
\hline $\begin{array}{l}\text { A megfelelöség (compli- } \\
\text { ance) meghatározása és } \\
\text { biztosítása minimums- } \\
\text { tandardok révén }\end{array}$ & $\begin{array}{l}\text { Minimumstandardok és } \\
\text { célok meghatározása, } \\
\text { érvényesítő és ellenőrző } \\
\text { mechanizmusok létre- } \\
\text { hozása, polgári akciók } \\
\text { támogatása }\end{array}$ & \begin{tabular}{|l|} 
Adózási ösztönzők és bün- \\
tetések, az információelérés \\
biztosítása, a minimálisan \\
elégséges jó gyakorlat megér- \\
tésének facilitálása, a gyen- \\
gén teljesítők megnevezése \\
és megszégyenitése, önkéntes \\
megegyezések keretrendsze- \\
re, a civil társadalom támo- \\
gatása
\end{tabular} & $\begin{array}{l}\text { Multilaterális ügynöksé- } \\
\text { gekkel és a civil társada- } \\
\text { lommal végzett munka a } \\
\text { kapacitásépítés érdekében }\end{array}$ & \\
\hline $\begin{array}{l}\text { A politikai döntések által } \\
\text { kialakított szabályozási } \\
\text { környezet, a közcélú } \\
\text { szabályozás (public poli- } \\
\text { cy) az üzleti szervezetek } \\
\text { számára }\end{array}$ & $\begin{array}{l}\text { A politikai alapú fi- } \\
\text { nanszírozás reformja, } \\
\text { jogalkotás (mint poli- } \\
\text { cy-alkotás) az önkéntes } \\
\text { tevékenységekre, a } \\
\text { közszervezetek fizetési } \\
\text { folyamatainak kötelező } \\
\text { közzététele } \\
\end{array}$ & \begin{tabular}{|l|} 
Az üzleti szervezetek elköte- \\
lezése a közcélú szabályozási \\
folyamatokra, társadalmi-kö- \\
zösségi prioritások (beleértve \\
tetszőleges CSR-elemeket) \\
világos meghatározása
\end{tabular} & $\begin{array}{l}\text { A közcélú szabályozási } \\
\text { folyamatok fórumainak } \\
\text { és vitáinak megteremtése }\end{array}$ & $\begin{array}{l}\text { Az üzleti képviselők } \\
\text { integrálása a ,poli- } \\
\text { cy-arénában”" }\end{array}$ \\
\hline $\begin{array}{l}\text { Vállalati kormányzás } \\
\text { (corporate governance) }\end{array}$ & $\begin{array}{l}\text { Tőzsdeszabályozás, társa- } \\
\text { sági jog }\end{array}$ & $\begin{array}{l}\text { Nemzetközi irányelvek imp- } \\
\text { lementálása }\end{array}$ & $\begin{array}{l}\text { Multi-stakeholder szabá- } \\
\text { lyozás }\end{array}$ & $\begin{array}{l}\text { Mérőszámok } \\
\text { és indikátorok } \\
\text { jóváhagyása, civil } \\
\text { kezdeményezések } \\
\text { támogatása } \\
\end{array}$ \\
\hline Felelős beruházások & $\begin{array}{l}\text { FDI (Foreign Direct } \\
\text { Investment) irányelvek, } \\
\text { kormányzati bérgaranci- } \\
\text { ák követelménye }\end{array}$ & $\begin{array}{l}\text { A fenntartható, felelös, hatá- } \\
\text { sos beruházások (SRI, Susta- } \\
\text { inable, Responsible, Impact } \\
\text { Investing) szabályozásának } \\
\text { facilitálása, közösségi beru- } \\
\text { házások keretrendszerének } \\
\text { kezdeményezése, a fenntart- } \\
\text { ható fejlődést segítő beruhá- } \\
\text { zási lehetőségek éltetése }\end{array}$ & $\begin{array}{l}\text { Public-private kapcsola- } \\
\text { tok erösítése }\end{array}$ & \\
\hline $\begin{array}{l}\text { Filantrópia és közösség- } \\
\text { fejlesztés }\end{array}$ & $\begin{array}{l}\text { Társasági hozzájárulások } \\
\text { és közreműködések nor- } \\
\text { mázása }\end{array}$ & $\begin{array}{l}\text { Adózási ösztönzők, időbank } \\
\text { sémák, a nyomásgyakorlást } \\
\text { népszerüsítő eszközök }\end{array}$ & $\begin{array}{l}\text { Public-private kapcsola- } \\
\text { tok erösítése }\end{array}$ & $\begin{array}{l}\text { Az élenjáró üzleti/tár- } \\
\text { sasági adományozók } \\
\text { publikálása }\end{array}$ \\
\hline $\begin{array}{l}\text { Stakeholder elkötelezett- } \\
\text { ség és reprezentáció }\end{array}$ & $\begin{array}{l}\text { Az érintett-konzultáció } \\
\text { kereteinek, követelmé- } \\
\text { nyeinek engedélyezése }\end{array}$ & $\begin{array}{l}\text { Civil társadalmi elkötelezö- } \\
\text { dés támogatása, a kritikus } \\
\text { fórumokon a kritikus érintet- } \\
\text { tek érdekeinek védelme }\end{array}$ & $\begin{array}{l}\text { A dialógus facilitálása, } \\
\text { multi-stakeholder fo- } \\
\text { lyamatok támogatása, } \\
\text { kísérése }\end{array}$ & $\begin{array}{l}\text { Egyedi multi-stake- } \\
\text { holder folyamatokhoz } \\
\text { való kapcsolódás }\end{array}$ \\
\hline $\begin{array}{l}\text { Pro-CSR termelés és } \\
\text { fogyasztás }\end{array}$ & $\begin{array}{l}\text { Kibocsátási adók, a } \\
\text { pro-CSR innovációk } \\
\text { serkentésére ,utasítás és } \\
\text { ellenőrzés” logikájú sza- } \\
\text { bályalkotás }\end{array}$ & $\begin{array}{l}\text { Pro-CSR exportkezdeménye- } \\
\text { zések, kapacitásképzés, üzleti } \\
\text { tanácsadási szolgáltatások, } \\
\text { vállalkozásfejlesztés, köz- } \\
\text { beszerzés, ,önkéntes CSR” } \\
\text { címkék, oktatás és tudatos- } \\
\text { ság-növelés, civil kezdemé- } \\
\text { nyezések támogatása, adózási } \\
\text { ösztönzők }\end{array}$ & $\begin{array}{l}\text { Közös kormányzati - ipa- } \\
\text { ri beruházási kapacitások } \\
\text { teremtése; szektorirányel- } \\
\text { vek megalkotása }\end{array}$ & $\begin{array}{l}\text { Közbeszerzés, pro- } \\
\text { CSR menedzsment } \\
\text { közszolgálati intéz- } \\
\text { ményeknél, címkézési } \\
\text { sémák }\end{array}$ \\
\hline $\begin{array}{l}\text { Pro-CSR minősítés, } \\
\text { a megfelelőségen túli } \\
\text { standardok és irányítási } \\
\text { rendszerek }\end{array}$ & $\begin{array}{l}\text { A környezeti felelösség } \\
\text { kötelező szervezeti irá- } \\
\text { nyítási rendszerei }\end{array}$ & \begin{tabular}{|l|} 
Információ- és kapacitás- \\
képzés, B2B partnerképzés, \\
mentorálás támogatása, \\
közbeszerzés, adózási és \\
szabályozási ösztönzők, \\
az értékláncot érintő \\
kezdeményezések és önkéntes \\
minősítések támogatása \\
\end{tabular} & $\begin{array}{l}\text { Elkötelezettség a standar- } \\
\text { dok létrehozásában }\end{array}$ & $\begin{array}{l}\text { Specifikus standard- } \\
\text { rendszerek és meg- } \\
\text { közelítések/modellek } \\
\text { jóváhagyása, közbe- } \\
\text { szerzés és közszolgá- } \\
\text { lati gyakorlat }\end{array}$ \\
\hline $\begin{array}{l}\text { Pro-CSR beszámolás és } \\
\text { átláthatóság }\end{array}$ & Kötelező beszámolás & $\begin{array}{l}\text { Kötelező beszámolás irányel- } \\
\text { vei, informális kezdeménye- } \\
\text { zések }\end{array}$ & $\begin{array}{l}\text { Elkötelezettség a mul- } \\
\text { ti-stakeholder diskur- } \\
\text { zusban }\end{array}$ & $\begin{array}{l}\text { A nyomásgyakorlás } \\
\text { támogató eszközei, } \\
\text { ajánlott riporterek, } \\
\text { szószólók }\end{array}$ \\
\hline $\begin{array}{l}\text { Többoldalú folyamatok, } \\
\text { irányelvek és konvenciók }\end{array}$ & $\begin{array}{l}\text { Irányelvek implemen- } \\
\text { tálása a jogalkotáson } \\
\text { keresztül }\end{array}$ & $\begin{array}{l}\text { Kapacitásképzés és technikai } \\
\text { támogatás }\end{array}$ & $\begin{array}{l}\text { Tárgyalási megállapo- } \\
\text { dások, megosztott moni- } \\
\text { toring }\end{array}$ & $\begin{array}{l}\text { Irányelvek jóváha- } \\
\text { gyása }\end{array}$ \\
\hline
\end{tabular}


önmagunk felé és a körülöttünk élök felé egyaránt mutat. S így lesz aztán közösségi, szervezeti fókuszú is: az emberek által alkotott szervezetek minőségének, kapcsolatrendszerének eleme. S e mentén jutunk el odáig, hogy tárgyiasul, „kint van”, elemezhető, formálható.

Jelen tanulmányunkban a szervezeti egyén felelősségének körülhatárolására törekedtünk. Úgy véljük, lényeges, hogy ki (az alany) felel kiért/miért (tárgy), kinek vagy minek (részeshatározó). A felelősségtudatot és a felelős cselekvést ehhez kapcsolódva a szervezeti egyén, a szervezeti közegbe beágyazott ember vonatkozásában kutatjuk.

\section{A felelősségvállalás kutatásának szintjei}

A felelősséggel és a felelősségvállalással kapcsolatos gazdaságtudományi kutatások tradíciója gazdag. A hazai doktori munkák között az utóbbi időben mind gyakoribb az egyéni és a szervezeti felelősségvállalás jelenségének, gyakorlatának vizsgálata, s egyéni szinten a vállalatvezetők, az „értékvezérelt vezetés” elemzése is (lásd pl. Győri, 2010; Veszprémi, 2010; Szabó-Benedek, 2014; Kovács, 2015; Gering, 2015).

Bodorkós és Pataki (2012) értékes elemzésükben a nemzetközi társadalmi felelősségvállalás szakirodalmának empirikus kutatásait módszertanilag tekintik át. Bemutatják az empirikus kutatások leggyakoribb tárgyait, a kutatások szintjeit és részletes képet adnak az alkalmazott kvalitatív és kvantitatív módszertanokról.

Amint a szerzők leírják, a kutatások leggyakoribb szintje a vállalatok szintje, azon belül is leginkább esettanulmányokat találhatunk. Ezek az esetelemzések alapvetően a jó és rossz vállalati példák elemzésére törekszenek, a vállalat egy-egy konkrét területen végzett társadalmi felelősségi tevékenységét vizsgálják (pl. munkavállalókkal való bánásmód, gyerekmunka, etikai kódex bevezetése, kommunikáció). A kutatók következtetéseket és ajánlásokat is megfogalmaznak a hazai kutatások számára, így többek között az alábbiakra hívják fel a figyelmet:

- kelet-közép-európai, a rendszerváltás utáni trendeket vizsgáló kutatásokat szinte alig találtak,

- a már lezárult kutatások leginkább a közép- és felső vezetésre vonatkoztak, az operatív szint vizsgálata elmaradt,

- a kutatások zöme kisszámú (általában legfeljebb kettő) adatgyüjtési technikát alkalmazott, valamint nem jellemző a kvalitatív és kvantitatív módszerek kombinálása sem, amely mélyebb rálátást adna a felelősség komplex jelenségére és jobban biztosítaná a trianguláció lehetőségét,

- tudományfilozófiai, de sok esetben még a konkrét empirikus kutatás kapcsán alkalmazott elméleti háttérre vonatkozó leírások is igen hiányosak a vizsgált tanulmányokban,

- a vállalatok egészét, például az intézményesülést átfogó kutatások nem igazán találhatók egyelőre; egyegy konkrét vállalati funkcionális területhez kapcsolódóan valósulnak meg.

\section{Kutatási alapállás és szándék}

Kutatásunk indulásakor a felelősség és a felelősségvállalás fogalmának megértése volt a célunk, ám a hazai diskurzust olyan elemmel szerettük volna színesíteni, ami a „felelős szervezeti embert” helyezi a középpontba. A konstruktivista szervezetelméleti alapállást (Kieser,1995) tudjuk magunkénak, a felelősség interszubjektív módon, helyileg értelmezett jelentéseinek feltárására összpontosítunk, miközben a háttérben modellünk továbbformálásán dolgozunk. Úgy véljük, a felelősség alapvetően a megértő létmódon keresztül, adott szervezeti jelentésközösségben közelíthetö, tárható fel valóságosan (Gelei, 2006). Az adatgyüjtésben több technikát alkalmazva a triangulációra törekszünk.

Tanulmánysorozatunk következő, második darabjában egy közszolgálati szervezet következik, majd egy gazdasági társaság munkatársai körében, a „felelősség” értelmezése érdekében végzett vizsgálódásunkat mutatjuk be. Ezt követően diákok felelősségértelmezését és tanulásuk iránti felelősségvállalási attitűdjeit elemezzük. Így kívánjuk gazdagítani (sok szempontból talán hiányt pótolni) a szervezeti felelősségvállalás hazai kutatási diskurzusát.

\section{Összefoglalás}

A szervezeti felelősségvállalás az egyéni felelősségvállalással (az azzal való találkozással, annak tudatosításával, s az elvállalás kognitív és érzelmi lépésével) kezdődik - és ott is ér véget. Cikkünk azzal a céllal íródott, hogy hozzájáruljon a felelős szervezeti ember fogalmának tisztázásához.

A szervezeti felelősségvállalás összetett jelenség, egyének együttműködéséből alakul. Tanulmányunk az egyéni szint után üzleti és nem-üzleti küldetésü szervezetek esetében vizsgálta a felelősségvállalás lehetséges jelentését, módját. Az általánosítás lelkületével rámutattunk azokra az elemekre, ahol ez a tapasztalatok szerint sérülékennyé válhat - a felelősségvállalás jelensége ugyanakkor szervezetileg egyedi. Meggyőződésünk, hogy kutatása csak az interpretatív paradigmában képzelhető el, ennek kutatási lépcsőit járjuk most és a következőkben.

\section{Jegyzet}

1 A felelősség és a bizalom kapcsolatára mutat rá például a 2008-as válság, s az abban tetten érhető bizalomvesztési folyamat. A pénzügyi válság során a spekuláció tárgyai olyan pénzügyi termékek - például a subprime jelzáloghitelek - voltak, melyek tulajdonságairól, kockázatairól a befektetők nem rendelkeztek teljes körü információkkal. A hiányt a pénzintézetek működésébe vetett bizalom és a rendkívül sok szereplő között megoszló kockázat helyettesítette (Szanyi, 2009). A bankok és hitelminősítők közötti magas üzleti öszszefonódás következményei a rendszer müködésébe vetett bizalmat alapjaiban rengették meg. Miután a Lehman Brothers csődöt mondott, és a tulajdonos mellett a befektetők is elvesztették vagyonukat, a bizalomveszteség olyan mértékűvé vált, hogy a bankok már egymásnak sem mertek hitelt biztosítani. Ez pedig sok ágazatban a likviditás megszűnéséhez vezetett. Ebből is látszik, hogy könnyen hajlamosak vagyunk egy másik személyt, szervezetet bizalmi kapcsolat mentén felelösséggel felruházni, még ha ez más oldalról nézve nem is racionális. 


\section{Felhasznált irodalom}

Angus-Leppan, T. - Metcalf, L. - Benn, S. (2010): Leadership Styles and CSR Practice: An Examination of Sensemaking, Intitutional Drivers and CSR Leadership. Journal of Business Ethics, 93. kötet, p. 189-213.

Bábosik, I. (2004): Neveléselmélet. Budapest: Osiris Kiadó

Bakacsi, Gy. (1998): Szervezeti magatartás és vezetés. Budapest: Közgazdasági és Jogi Könyvkiadó

Bakacsi, Gy. (2010): A szervezeti magatartás alapjai. Budapest: Aula

Battles, B. (2005): Directing: Accomplishing objectives through delegation and motivation. Aircraft Maintenance Technology, 16(5), p. 38-41.

Bodzási, B. (2014): A korlátolt felelősségű társaság. Társasági Jog tantárgy. Budapest: Corvinus Egyetem

Bodorkós B. - Pataki Gy. (2012): Hogyan kutassuk a CSR-t? A nemzetközi szakirodalom empirikus kutatásainak módszertani áttekintése. BCE, 148. sz. Mühelytanulmány; HU ISSN 1786-3031

Carroll, A. B. (1991): The Pyramid of Corporate Social Responsiblity: Toward the Moral Management of Organizational Stakeholders. Business Horizons, július augusztus, p. 39-48.

Chen, S. - Bouvain, P. (2009): Is Coporate Responsiblity Converging? A Comparison of Corporate Responsiblity Reporting in the USA, UK, Australia and Germany. Journal of Business Ethics, 87., p. 299-317.

Christensen, L. J. - Mackey, A. - Whetten, D. (2014): Taking Responsiblity for Corporate Social Responsibility: The Role of Leaders in Creating, Implementing, Sustaining or Avoiding Socially Responsible Firm Behaviors. The Academy of Management Persepectives, 28., p. 164-178.

Clements, M. - Bowrey, G. (2010): Corporate social responsibility in public sector supply chains: an insight. Journal of New Business Ideas and Trends, 8 (2), p. 1-13.

Crowther, D. - Aras, G. (2008): Governance and Responsibility: An Investigation into the Relationship between Corporate Governance and Corporate Sustainablity. Management Decision, 46(3), p. 433-448.

de Rooij, E. (1996): A brief desk research study into the average life expectancy of companies in a number of countries. Amsterdam: Stratix Consulting Group.

Eckley, P. (2015): An Economy of Relationships. Berlin: Biblenomics Conference

Elkington, J. (1997): Cannibals With Forks: The Triple Bottom of 21st Century Business. Oxford: Capstone Publishing Ltd.

Etymonline (2001): www.etymonline.com. (Online) Megtekinthetö: http://www.etymonline.com/index.php?allowed_in_frame $=0 \&$ search $=$ responsibility\&searchmode=none (Hozzáférés dátuma: 25. március 2015).

European Comission (2001): Green Paper: Promoting a European Framework for Corporate Social Responsiblity. Brüsszel

Fox, T. - Ward, P. - Howard, B. (2002): Public Sector Roles in Strengthening Corporate Social Responsibility: A Baseline Study. (Online) Megte- kinthetö: http://documents.worldbank.org/curated/ en/284431468340215496/pdf/346550CSR1CSR1interior.pdf (Hozzáférés dátuma: 10. november 2016)

Frankena, W. K. (1980): Thinking About Morality. Ann Arbor: University of Michigan Press

French, P. A. (1979): The Corporation as a Moral Person. American Philosophical Quarterly, 16(3), p. 207-215.

Friedman, M. (1970): The Social Responsibility of Business is to Increase Its Profits. The New York Times Magazine, 13 Szeptember

Gelei A. (2006): A szervezet interpretatív megközelítése. Vezetéstudomány, XXXVIII. évf., Különszám, p. 7997.

Gelei, A. (2011): A szervezet interpretatív megközelítése. in: R. Glózer - A. Gelei (szerk.) (2011): Valóságkonstrukciók: A szervezeti jelentésvilág interpretatív megközelítései. Budapest: Gondolat Kiadó

Gering Zs. (2015): A vállalati társadalmi felelősségvállalás on-line diskurzusa. Doktori értekezés. Budapest: BCE

Goodpaster, K. E. - Matthews, J. B. J. (1982): Can a corporation have a conscience? Harvard Business Review, Issue January-February, p. 132-141.

Greenfield, K. (2015): Corporate Law's Original Sin. Washington Monthly, Január/Február, p. 29-30.

Greiner, L. E. (1972): Evolution and Revolution as Organizations Grow. Harvard Business Review, 50(4), p. 37-46.

Győri Zs. (2010): CSR-en innen és túl. Doktori értekezés. Budapest: BCE

Hack, L. - Kenyon, A. - Wood, E. (2014): A Critical Corporate Social Responsibility (CSR) Timeline: How should it be understood now? International Journal of Management Cases, 16(4), p. 46-55.

Hankiss A. (2002): Kötéltánc. in: Lengyel Zs. (2002): Szociálpszichológia. Budapest: Osiris

Jones, T. (1980): Corporate Social Responsibility Revisited, Redifined. California Management Review, 22(22), p. 59-67.

Juhász J. - Szőke I. - O. Nagy G. - Kovalovszky M. (1992): Magyar Értelmező Kéziszótár. Budapest: Akadémiai Kiadó

Kim, D. - Fisher, D. - McCalman, D. (2009): Modernism, Christianity, and Business Ethics: A Worldview of Perspective. Journal of Business Ethics, 90. kötet, p. $115-121$.

Kiss N. - Révész É. (2011): Teljesítménymenedzsment a közszektorban. in: Közszolgálati szervezetek vezetése. Egyetemi jegyzet. Budapest: Aula Kiadó

Kovács I. (2015): A társadalmilag felelős fogyasztói magatartás jellemzőinek vizsgálata. Doktori értekezés. Gödöllő: Szent István Egyetem

Korten, D. C. (1996): Tőkés társaságok világuralma. Budapest: Kapu

Kundera, M. (1992): A lét elviselhetetlen könnyüsége. Budapest: Európa Könyvkiadó

Kuti É. (1998): Hívjuk talán nonprofitnak... Budapest: Nonprofit Kutatócsoport

Newman, J. P. (1969): A Letter to the Duke of Norfolk 5: Certain Difficulties felt by Anglicans in Catholic Teaching, 2. köt., Westminster 
Porter, M. E. - Kramer, M. R. (2011): Creating Shared Value. Harvard Business Review, Január/Február, p. 63 - 77.

Ruiz-Palomina, P. - Ruiz-Amaya, C. (2011): Factores determinantes del comportamiento ético/no ético del empleado: una revisión de la riteratura. Investigaciones Europead de Dirección y Economía de la Empresa, 17., p. 23-29.

Siegel, D. - Yancey, J. (1992): A civil társadalom újjászületése. Budapest: The Rockefeller Brothers Fund

Simon, H. (1982): Korlátozott racionalitás : Válogatott tanulmányok. Budapest: Közgazdasági és Jogi Könyvkiadó

Schein, E. (1996): The Missing Concept in Organization Studies. Administrative Science Quaterly, 41(2), p. 229-240.

Schulter, M. (2000): Risk, Reward and Responsibility: Limited Liability and Company Reform. Cambridge Papers Towards A Biblical Mind, 9(2), p. 1-6.

Schütz, C. (1993): A keresztény szellemiség lexikona. (Online) Megtekinthető: http://mek.oszk.hu/adatbazis/lexikon/phplex/lexikon/d/katlex/s044.html (Hozzáférés dátuma: 2017. január. 9.)

Szabó-Benedek A. (2014): A CSR-gyakorlat vizsgálata a vállalatvezetői értékek és attitűdök tükrében. Doktori értekezés. Gödöllő: Szent István Egyetem

Szanyi M. (2009): A globális válság eredete, fö dimenziói és egyéb jellemzői. A globális válság: hatások, gazdaságpolitikai válaszok és kilátások. p. 7-26.
Szent Ágoston (1989): A boldog életről. A szabad akaratról. Budapest: Európa Kiadó

Tarró A (2012): A transznacionális vállalatok világgazdasági jelentősége: a megítélés és a szabályozás lehetőségei. E-CONOM, p. 14-27.

Thesaurus (2013): www.thesaurus.com. (Online) Megtekinthetö: http://www.thesaurus.com/browse/responsibility (Hozzáférés dátuma: 25. március 2015)

Tóth G. (2007): A valóban felelős vállalat. Budapest: KÖVET

United Nations Global Compact (2008): The Practical Guide to the United Nations Global Compact Communication on Progress.

Veres A. (1993): Erkölcsteológia I. Jegyzet. (Online) Megtekinthető:

www.szentmartonegyesulet.org/ftk/erkolcsteologiaI.doc (Hozzáférés dátuma: 7. december 2016)

Vidal, P. - Torres, D. (2005): The Social Responsibility of Non-Profit Organizations. Barcelona: Observatori del Tercer Sector

Veszprémi B. (2010): A köztisztviselők felelősségi rendszere. Doktori értekezés. Miskolc: Miskolci Egyetem

Werner, K. - Weiss, H. (2006): Márkacégek feketekönyve. Budapest: Art Nouveau Kiadó

Zaicz G. (2006): Etimológiai szótár. Magyar szavak és toldalékok eredete. Budapest: Tinta Könyvkiadó. 